\title{
Amino Acid Patterns in Cystinuric Families
}

\author{
SALLY KELLY and W. COPELAND
}

\begin{abstract}
From the Division of Laboratories and Research, New York State Department of Health, Albany, N.Y., U.S.A.
\end{abstract}
The delineation of cystinuria into two types, 'recessive' and 'incompletely recessive', according to a differential expression of the gene defect in carriers by urinary parameters (Harris et al., 1955a, b), has been further refined into three forms by including in phenotype analysis evidence for heterogeneity (Rosenberg, 1966; Rosenberg et al., 1966) of the accompanying intestinal transport defect in stone formers (Asatoor et al., 1962; Milne et al., 1961). Thus, the 'recessive' of Harris resembles the Type I form of Rosenberg, in which the stone formers lack active transport systems in the gut for cystine and the basic amino acids, and the carriers excrete normal amounts of these amino acids; the 'incomplete recessives' fall into either Type III without the intestinal defect in the stone formers and with intermediate levels of excess excretion by the carriers, or into Type II with a partial transport defect and with grosser excretory excesses by the carriers.

Our report describes the amino acid excretion of 35 members of three cystinuric families ${ }^{\star}$, attempts to classify the gene defects by urinary parameters only, and evaluates the excretion of the disulphide, cysteine-homocysteine (Frimpter, 1961, 1963), as a key to the carrier state.

\section{Materials and Methods}

Urine samples were collected with refrigeration and $\mathrm{HCl}$ as preservatives, from 2 stone formers and 20 non-stone formers in 4 generations of Family $M$ (Fig. 1); from 2 stone formers and 6 non-stone formers in 3 generations of Family BF; and from 1 stone former and 4 non-stone formers in 2 generations of Family F. The stone formers were young adults between the ages of 18 and 34 years, who were recognized as cystinurics while in their teens. All but F II. 1 had undergone operations for stone at least once and were receiving low methionine diets and penicillamine. None were in renal failure at the time of sampling; all but $M$ III. 2 were relatively well and functional between attacks.

Received January 8, 1968.

* Patients' samples, histories, and diagnoses were made available by Drs. A. V. Passaretti and E. P. Nolan of Albany, New York.
They were screened for abnormalities in cystine metabolism by nitroprusside (Brand, Harris, and Biloon, 1930) and one-dimensional paper chromatography (Efron et al., 1964; Scriver, Davies, and Cullen, 1964) of $5 \mathrm{ml}$. and $10 \lambda$ aliquots, respectively. The daily excretory rates of pertinent amino acids and disulphides were calculated from quantitative assays of $0.5 \mathrm{ml}$. aliquots of the samples in a Beckman $120^{\circ} \mathrm{C}$. analyser, after a schedule for physiological samples (Beckman Spinco), with the exceptions that buffer of $p \mathrm{H} 3.21$ was used on the $58 \mathrm{~cm}$. column to separate cystine from valine, and the buffer change to $\mathrm{pH} 4.25$ was delayed 40 minutes to allow for resolution of the penicillamine disulphides. In samples with incomplete resolution of the disulphide, cysteine-homocysteine, from leucine, the peaks were separated in a rechromatography, with the buffer change postponed for an additional 150 minutes.

Urine samples interpreted as containing excess cystine by the nitroprusside reaction were later found by column chromatography to have cystine concentrations of at least $40 \mathrm{mg}$./g. Cr. Estimates by paper chromatography of excess cystine, lysine, and arginine excretion were semiquantitative, in that the ninhydrin densities were compared with those of a series of solutions of known amino acid concentration developed simultaneously; the excretion rates were considered excessive if they were greater than those estimated from similar paper chromatograms of 24-hour urine samples from 9 normal children, aged 3 to 13 years, and from 10 normal adults. Excretory rates of the specific amino acids calculated from quantitative column chromatography were considered in excess if they were greater than previously published rates for adults and children under 16 years (Kennedy, Shih, and Rowland, 1965).

The amino acids were identified as peaks in column chromatograms with elution schedules coincident with those of amino acids in normal urine (Beckman Spinco), in the Beckman Amino Acid Calibration Mixture, Type 1 , or of known amino acids chromatographed under comparable column conditions. A few were identified by their additive effects on chromatograms of previously analysed urine samples enriched with known amino acids. The disulphides, cysteine-homocysteine, dipenicillamine, and penicillamine-cysteine were identified as peaks with coincident elution schedules or with additive effects in urine, when compared with those of solutions of the component amino acids converted to the disulphides during 4 hours at room temperature, with hydrogen ion concentrations adjusted to $p \mathrm{H} 8.0$ with 


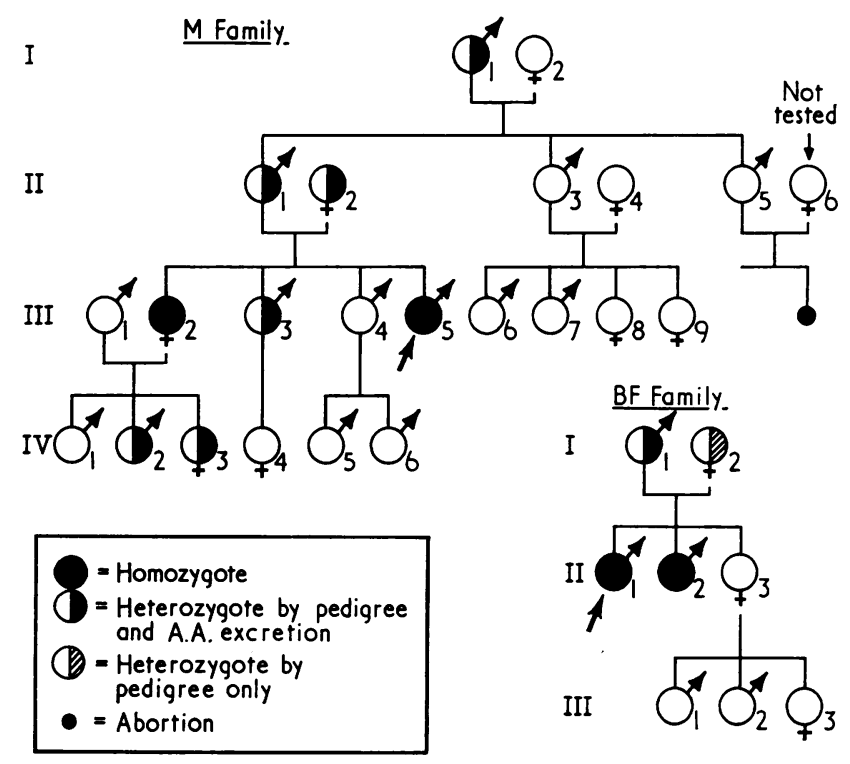

FIG. 1. Cystinuria genotypes in the $M$ and $B F$ families by pedigree and amino acid excretion.

sodium hydroxide before chromatography (Frimpter, 1961; Stein and Moore, 1954). Cysteine-homocysteine was further distinguished by its greater 440:570 $\mathrm{m} \mu$ absorption ratio (Frimpter, 1961), and by its disappearance from chromatograms of samples oxidized with performic acid (Bartter et al., 1965; Schram, Moore, and Bigwood, 1954).

\section{Results}

That the stone formers excreted excessive amounts of cystine and the basic amino acids was clear from nitroprusside reactions, paper chromatography, and column chromatography. Six nonstone formers also had nitroprusside-reacting urine, five from Family $M$ and one from Family BF, verified in five as due primarily to cystine excess by paper and column chromatography. One child with nitroprusside-reacting urine, $M$ IV. 1 , excreted normal amounts of cystine and the basic amino acids and was excluded here as a carrier. Two additional non-stone formers of Family $M$ (Fig. 1) excreted cystine in excess, determined by column chromatography. The cystinuria of the seven non-stone formers was accompanied by excessive excretion of the basic amino acids, demonstrable in all by column chromatography and, in three, by paper chromatography.

The degree of excessive urinary excretion of cystine and the basic amino acids in the six nonstone formers of the $M$ family was in the intermediate' range (Rosenberg et al., 1966) (Table I) and suggests that they are carriers of the Type III 'incompletely recessive' form. Conversely, the failure to detect these excesses in the non-stong formers of Family F (Table II), including the onl living parent, concurs with interpretation of the disease in this family as typical of the Type $I$ 'recessive' form (Rosenberg et al., 1966), and prevents the identification of carriers among sibs by these urinary parameters alone. The normal excretion of these amino acids by BF I. 2 and the intermediate levels of excessive excretion by BF I. 1 suggest that the parents in Family BF (Table III) are carriers of the Type I 'recessive' and the Type III 'incompletely recessive' forms, respectively, and that the two stone-forming sons are 'doubly heterozygous' (Rosenberg, 1966). Consequently, the identification of the carrier state in the sib, BF II. 3, and her offspring, BF III. 1, 2, and 3, by these urinary parameters alone is as uncertain as it is in sibs of the F family, except for the knowledge that they are apparently not carrying the Type III form.

The disulphide, cysteine-homocysteine, was excreted by all the stone formers (Frimpter, 1961, 1963) and, in greater than trace amounts ( $>2.5$ mg./day), by six of the seven Type III carriers and by a non-cystinuric male construction worker of Family M, III. 4. None of the F family, save the stone former, excreted the disulphide in more than trace amounts. Less than $2.5 \mathrm{mg}$./day was chosen as within the normal range of excretion, since the two non-cystinuric unrelated spouses in 
TABLE I

AMINO ACID EXCRETION RATES IN M FAMILY

(mg./24 hr.)

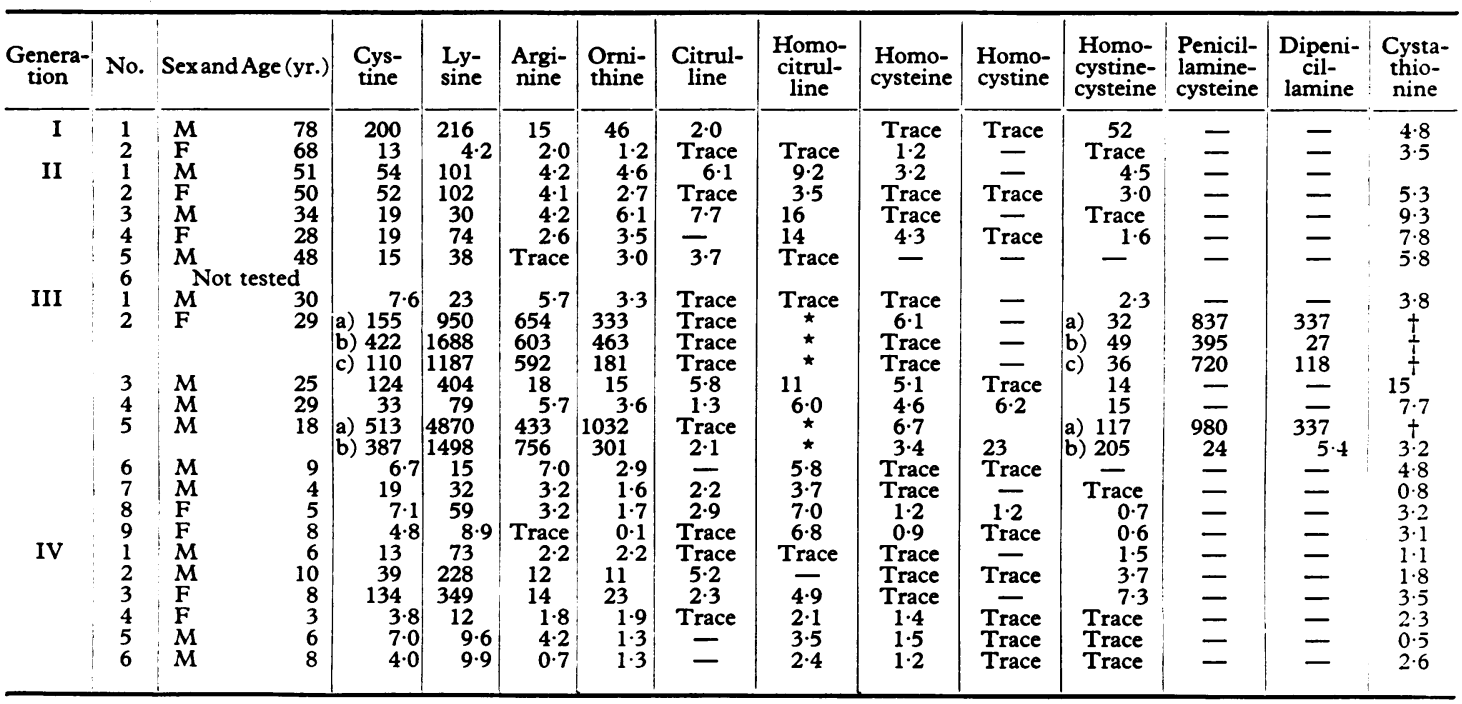

* Interference by penicillamine-cysteine.

+ Interference by penicillamine disulphide.

TABLE II

AMINO ACID EXCRETION RATES IN F FAMILY

(mg./24 hr.)

\begin{tabular}{|c|c|c|c|c|c|c|c|c|c|c|c|c|c|}
\hline $\begin{array}{c}\text { Genera- } \\
\text { tion }\end{array}$ & No. & Sex a & (yr.) & Cystine & Lysine & Arginine & Ornithine & $\underset{\text { line }}{\text { Citrul- }}$ & $\begin{array}{l}\text { Homo- } \\
\text { citrul- } \\
\text { line }\end{array}$ & $\begin{array}{l}\text { Homo- } \\
\text { cysteine }\end{array}$ & $\begin{array}{l}\text { Homo- } \\
\text { cystine }\end{array}$ & $\begin{array}{l}\text { Homo- } \\
\text { cystine- } \\
\text { cysteine }\end{array}$ & $\begin{array}{l}\text { Cysta- } \\
\text { thionine }\end{array}$ \\
\hline II & $\begin{array}{l}1 \\
1 \\
2 \\
3 \\
4\end{array}$ & $\begin{array}{l}F \\
M \\
F \\
F \\
M\end{array}$ & $\begin{array}{l}45 \\
23 \\
15 \\
22 \\
10\end{array}$ & $\begin{array}{r}11 \\
205 \\
7.6 \\
7 \cdot 4 \\
5.9\end{array}$ & $\begin{array}{r}18 \\
837 \\
27 \\
41 \\
60\end{array}$ & $\begin{array}{c}2 \cdot 4 \\
513 \\
5 \cdot 1 \\
5 \cdot 0 \\
5 \cdot 7\end{array}$ & $\begin{array}{c}2 \cdot 1 \\
116 \\
2 \cdot 2 \\
3 \cdot 3 \\
2 \cdot 2\end{array}$ & $\begin{array}{c}\text { Trace } \\
\mathbf{5 \cdot 0} \\
\text { Trace } \\
\text { Trace }\end{array}$ & $\begin{array}{c}7.5 \\
\text { Trace } \\
2.9 \\
5.0 \\
3.0\end{array}$ & $\begin{array}{l}\text { Trace } \\
1 \cdot 1 \\
1 \cdot 1 \\
\text { Trace }\end{array}$ & $\begin{array}{c}\text { Trace } \\
- \\
-\end{array}$ & $\begin{array}{l}20^{1 \cdot 1} \\
\text { Trace } \\
\text { Trace }\end{array}$ & $\begin{array}{l}4 \cdot 0 \\
1 \cdot 9 \\
3 \cdot 7 \\
4 \cdot 0 \\
3 \cdot 1\end{array}$ \\
\hline
\end{tabular}

TABLE III

AMINO ACID EXCRETION RATES IN BF FAMILY (mg./24 hr.)

\begin{tabular}{|c|c|c|c|c|c|c|c|c|c|c|c|c|c|c|c|}
\hline $\begin{array}{c}\text { Genera- } \\
\text { tion }\end{array}$ & No. & Sex & (yr.) & $\begin{array}{l}\text { Cys- } \\
\text { tine }\end{array}$ & $\begin{array}{l}\text { Ly- } \\
\text { sine }\end{array}$ & $\begin{array}{l}\text { Argi- } \\
\text { nine }\end{array}$ & $\begin{array}{l}\text { Orni- } \\
\text { thine }\end{array}$ & $\underset{\text { line }}{\text { Citrul- }}$ & $\begin{array}{l}\text { Homo- } \\
\text { citrul- } \\
\text { line }\end{array}$ & $\begin{array}{l}\text { Homo- } \\
\text { cysteine }\end{array}$ & $\begin{array}{l}\text { Homo- } \\
\text { cystine }\end{array}$ & $\begin{array}{l}\text { Homo- } \\
\text { cystine- } \\
\text { cysteine }\end{array}$ & $\begin{array}{l}\text { Penicil- } \\
\text { lamine- } \\
\text { cysteine }\end{array}$ & $\begin{array}{c}\text { Dipeni- } \\
\text { cil- } \\
\text { lamine }\end{array}$ & $\begin{array}{l}\text { Cysta- } \\
\text { thio- } \\
\text { nine }\end{array}$ \\
\hline $\begin{array}{r}\text { I } \\
\text { II }\end{array}$ & $\begin{array}{l}1 \\
2 \\
1 \\
2 \\
3 \\
1 \\
2 \\
3\end{array}$ & $\begin{array}{l}\mathbf{M} \\
\mathbf{F} \\
\mathbf{M} \\
\mathbf{M} \\
\mathrm{F} \\
\mathbf{M} \\
\mathbf{M} \\
\mathbf{F}\end{array}$ & $\begin{array}{r}64 \\
60 \\
26 \\
34 \\
36 \\
10 \\
6 \\
9\end{array}$ & \begin{tabular}{|c}
88 \\
31 \\
164 \\
285 \\
22 \\
12 \\
$7 \cdot 2$ \\
$0 \cdot 3$
\end{tabular} & \begin{tabular}{|c|}
166 \\
81 \\
2326 \\
2434 \\
$4 \cdot 5$ \\
$9 \cdot 3$ \\
19 \\
$4 \cdot 2$
\end{tabular} & \begin{tabular}{|c|}
$9 \cdot 0$ \\
3.5 \\
508 \\
1065 \\
2.2 \\
1.1 \\
2.9 \\
1.4
\end{tabular} & \begin{tabular}{|c|}
9.2 \\
3.8 \\
331 \\
557 \\
Trace \\
1.3 \\
0.8 \\
0.8
\end{tabular} & $\begin{array}{c}3.7 \\
\text { Trace } \\
\text { Trace } \\
8.3 \\
- \\
\text { Trace } \\
-\end{array}$ & $\begin{array}{c}9 \cdot 3 \\
8 \cdot 2 \\
\star \\
\star \\
\frac{-}{3 \cdot 0} \\
\frac{-3 \cdot 7}{4}\end{array}$ & $\begin{array}{c}2.4 \\
2.3 \\
7 \cdot 9 \\
10 \\
\overline{1.5} \\
\text { Trace } \\
\text { Trace }\end{array}$ & $\begin{array}{c}\text { 二 } \\
\text { Trace } \\
\text { Trace } \\
\text { - } \\
\text { - }\end{array}$ & $\begin{array}{c}13 \\
2.0 \\
17 \\
19 \\
\text { Trace } \\
1.0 \\
\text { Trace } \\
\text { Trace }\end{array}$ & $\begin{array}{l}\text { 二 } \\
346 \\
891 \\
\text { - } \\
=\end{array}$ & $\begin{array}{l}- \\
183 \\
652 \\
= \\
=\end{array}$ & $\begin{array}{c}13 \\
4.5 \\
t \\
t \\
13 \\
4 \cdot 3 \\
3.9 \\
3.6\end{array}$ \\
\hline
\end{tabular}

* Interference by penicillamine-cysteine.

t Interference by penicillamine disulphide.

the $\mathbf{M}$ family, as well as the other non-cystinurics in the three families studied, excreted no more than that amount. Its slight excretion by one of the Type III carriers, M IV. 2, may be associated with his minimal degree of cystinuria, as the excretion rate of the mixed disulphide by the carriers approached a direct relation with that of cystine when excretion rates of cystine were less than $200 \mathrm{mg}$./day 


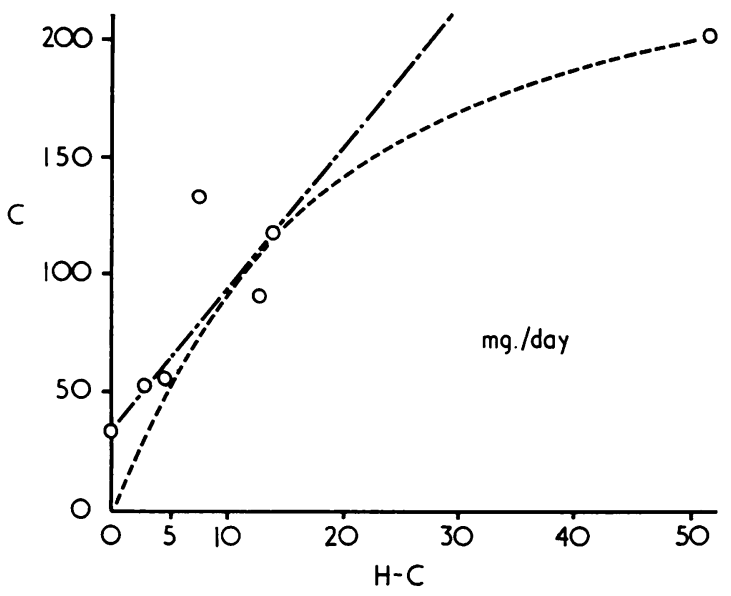

Fig. 2. The excretion of cystine and its mixed disulphide with homocysteine in carriers of Type III cystinuria.

(Fig. 2). This direct relation did not hold for the two excretion rates by stone formers, as has been previously noted (Frimpter, 1963).

Penicillamine disulphide and penicillaminecysteine were excreted by the four stone formers receiving the drug (Tables I and III). The former peak overlapped that of cystathionine in our elution schedules. The stone former not receiving penicillamine, F II. 1, excreted cystathionine in smaller amounts than did most of the non-stone formers.

Homocysteine and/or homocystine were excreted in more than trace amounts ( $>4.0 \mathrm{mg}$./day) by the four stone formers receiving penicillamine; F II. 1's failure to excrete it may have been a function of a lesser degree of cystinuria, though complex formation with cysteine in a highly alkaline urine was also possible.

Attention was paid to citrulline and homocitrulline with the expectation of their excretion by Type I cystinurics, after conversion by colonic bacteria from arginine (Asatoor et al., 1962; Milne, London, and Asatoor, 1962) and lysine (Ryan and Wells, 1964), respectively, not absorbed by jejunum, the site of intestinal transport defects.

Though citrulline was excreted in greater than trace amounts ( $>5 \mathrm{mg}$./day) by the stone former of the $\mathrm{F}$ family and by one from the BF family, who may have Type I and Type I-III defects, respectively, similar amounts were excreted by three carriers and by one non-carrier of the $M$ family. Sex and age, and their consequent differences in diet and personal habits, may have played a role here, rather than degree or type of cystinuria, since the women and children of the series excreted only trace amounts, regardless of cystinuria phenotype.
Similarly, the excretion of homocitrulline followed no discernible pattern in cystinuria phenotypes, nor was there a clear relation to sex. Age may have been a variable, as the younger children in families (all 3 years old or older) excreted the least amounts.

\section{Discussion}

Excretion of the disulphide, cysteine-homocysteine, by non-stone formers with cystinuria adds another dimension to our interpretations of cystinuric phenotypes. Its excretion is consistent with the finding in cystinurics of high clearance ratios for cystine (Crawhall et al., 1967) and the mixed disulphide (Frimpter, 1963), and with its interpretation as involving a renal tubular defect of cysteine secretion (Frimpter et al., 1962), if other SH-containing monomers, such as homocysteine, share the cellular mechanisms. Thus, the partial defect in carriers of the Type III form, known heretofore to be expressed by intermediate levels of cystine and basic amino acid excretory excesses, may also be reflected in the excretion of the mixed disulphide, whether of in vitro or in vivo origin. Its excretion by the noncystinuric, M III. 4, is a puzzle: is it a more sensitive key to the Type III carrier state or is it of dietary origin as described by Frimpter (1963) ? His two normal children and vigorous occupation lend support to the latter. Conversely, its traces. excretions by F I. 1 and BF I. 2 are consistent with Type I defects in these two apparent carriers (Rosenberg et al., 1966; Thier et al., 1964; Foley and London, 1965; McCarthy et al., 1964), if they include defects in the transfer of disulphides, as well (Frimpter, 1963; Spencer, Brody, and Mautner, 1965). Thus, the excretion pattern and defects in transport of the homogeneous disulphide, cystine, in Type I carriers (Rosenberg, Crawhall, and Segal, 1967) might well be accompanied by similar patterns and defects for the mixed disulphide.

The failure of cystinurics to excrete excess citrulline (Milne et al., 1962; Dent and Rose, 1951; Visakorpi, 1962) and homocitrulline, in spite of apparent Type I defects, may be related to the complexity of the biochemical lesions of cystinuria. While the nature of the intestinal defect has been well formulated (Rosenberg, 1966; Milne et al., 1961; Dent and Rose, 1951) and presently free of challenge, the renal defect has been arrived at largely by indirection, of necessity, and is subject, therefore, to controversy (Crawhall and Thompson, 1965; Rosenberg, Durant, and Holland, 1965). Thus, the fate of citrulline and homocitrulline may be masked by the larger problem of what is the renal defect of cystinuria. 


\section{Summary}

Carriers of cystinuria were identified in three families, and the diseases were classified by urinary parameters as probable Type I, Type III, and mixed Type I-III.

The gene defect in the Type III family was traced biochemically through four generations.

The excretion rate of the disulphide, cysteinehomocysteine, was added to criteria for the carrier state of the Types I and III forms. Citrulline and homocitrulline excretion rates did not help distinguish the phenotypes.

\section{REFERENCES}

Asatoor, A. M., Lacey, B. W., London, D. R., and Milne, M. D. (1962). Aminoacid metabolism in cystinuria. Clin. Sci., 23, 285.

Bartter, F. C., Lotz, M., Thier, S., Rosenberg, L. E., and Potts, J. T., Jr. (1965). Cystinuria. Ann. intern. Med., 62, 796.

Beckman Spinco DS-248. (1967). Accelerated Physiological Fluid Analyses.

Brand, E., Harris, M. M., and Biloon, S. (1930). Cystinuria. f. biol. Chem., 86, 315.

Crawhall, J. C., Scowen, E. F., Thompson, C. J., and Watts, R. W. E. (1967). The renal clearance of amino acids in cystinuria. f. clin. Invest., 46, 1162.

, and Thompson, C. J. (1965). Renal secretion of cystine in cystinuria. (Abstract.) ibid., 44, 1038.

Dent, C. E., and Rose, G. A. (1951). Aminoacid metabolism in cystinuria. Quart. F. Med., 20, 205.

Efron, M. L., Young, D., Moser, H. W., and MacCready, R. A. (1964). A simple chromatographic screening test for the detection of disorders of amino acid metabolism. A technic using whole blood or urine collected on filter paper. New Engl.f. Med., 270, 1378.

Foley, T. H., and London, D. R. (1965). Cysteine metabolism in cystinuria. Clin. Sci., 29, 549.

Frimpter, G. W. (1961). The disulfide of L-cysteine and L-homocysteine in urine of patients with cystinuria. f. biol. Chem., 236, PC51.
- (1963). Cystinuria: Metabolism of the disulfide of cysteine and homocysteine. f. clin. Invest., 42, 1956.

, Horwith, M., Furth, E., Fellows, R. E., and Thompson, D. D. (1962). Inulin and endogenous amino acid renal clearances in cystinuria. Evidence for tubular secretion. ibid., 41, 281.

Harris, H., Mittwoch, U., Robson, E. B., and Warren, F. L. (1955a). The pattern of amino-acid excretion in cystinuria. Ann. hum. Genet., 19, 196. cystinuria. ibid., 20,57.

Kennedy, C., Shih, V. E., and Rowland, L. P. (1965). Homocystinuria: A report in two siblings. Pediatrics, 36, 736.

McCarthy, C. F., Borland, J. L., Jr., Lynch, H. J., Jr., Owen, E. E., and Tyor, M. P. (1964). Defective uptake of basic amino acids and L-cystine by intestinal mucosa of patients with cystinuria. f. clin. Invest., 43, 1518.

Milne, M. D., Asatoor, A. M., Edwards, K. D. G., and Loughridge, L. W. (1961). The intestinal absorption defect in cystinuria. Gut, 2, 323.

-, London, D. R., and Asatoor, A. M. (1962). Citrullinuria in cases of cystinuria. Lancet, $2,49$.

Rosenberg, L. E. (1966). Cystinuria: Genetic heterogeneity and allelism. Science, 154, 1341.

-, Crawhall, J. C., and Segal, S. (1967). Intestinal transport of cystine and cysteine in man: Evidence for separate mechanisms. f. clin. Invest., 46, 30.

, Downing, S., Durant, J. L., and Segal, S. (1966). Cystinuria: Biochemical evidence for three genetically distinct diseases. ibid., 45, 365 .

- Durant, J. L., and Holland, J. M. (1965). Intestinal absorption and renal extraction of cystine and cysteine in cystinuria. New Engl. F. Med., 273, 1239.

Ryan, W. L., and Wells, I. C. (1964). Homocitrulline and homoarginine synthesis from lysine. Science, $144,1122$.

Schram, E., Moore, S., and Bigwood, E. J. (1954). Chromatographic determination of cystine as cysteic acid. Biochem. f., 57, 33.

Scriver, C. R., Davies, E., and Cullen, A. M. (1964). Application of a simple micromethod to the screening of plasma for a variety of aminoacidopathies. Lancet, 2, 230.

Spencer, R. P., Brody, K. R., and Mautner, H. G. (1965). Intestinal transport of cystine analogues. Nature (Lond.), 207, 418.

Stein, W. H., and Moore, S. (1954). The free amino acids of human blood plasma. F. biol. Chem., 211, 915.

Thier, S., Fox, M., Segal, S., and Rosenberg, L. E. (1964). Cystinuria: In vitro demonstration of an intestinal transport defect. Science, 143, 482.

Visakorpi, J. K. (1962). C Citrullinuria. Lancet, 1, 1357. 